Regular Article

\title{
Effect of Layer Thickness and Temperature Difference on Oxygen Diffusion Behavior in Thin Solution Layer Formed on Metal
}

\author{
Masatoshi SAKAIRI ${ }^{1)^{*}}$ and Masaya TANIGUCHI $^{2)}$ \\ 1) Faculty of Engineering, Hokkaido University \\ 2) Graduate School of Engineering, Hokkaido University, now Hitachi Construction Machinery Co., Ltd.
}

Abstract: One of the controlling factors for atmospheric corrosion is oxygen diffusion behavior in thin solution layer formed on metals. The oxygen diffusion limiting current in thin solution layer formed on Zn electrode was measured electrochemically to clarify the influence of solution layer thickness, temperature difference in the solution layer on the oxygen diffusion behavior. A solution of $10 \mathrm{mM} \mathrm{NaCl}$ was used as electrolyte to form solution layers. The solution layer thickness was controlled by masking adhesive tape with through holes. The environmental temperature, $T_{E}$, was controlled by circulating temperature-controlled water and the sample temperature, $T_{S}$, was controlled by a Peltier device. At $T_{E}=T_{S}$, the oxygen limiting current was independent of solution layer thickness. At $\mathrm{T}_{\mathrm{E}}<\mathrm{T}_{\mathrm{S}}$ and the solution layer thickness thinner than $0.6 \mathrm{~mm}$, the oxygen diffusion limiting current increased with thinning of the solution layer. The results suggest that $T_{E}$ and $T_{S}$ are also take into account as estimation of steel corrosion rate at snowy and cold region.

Keywords: Atmospheric corrosion; Oxygen diffusion limiting current; environmental temperature; specimen temperature; thin solution layer.

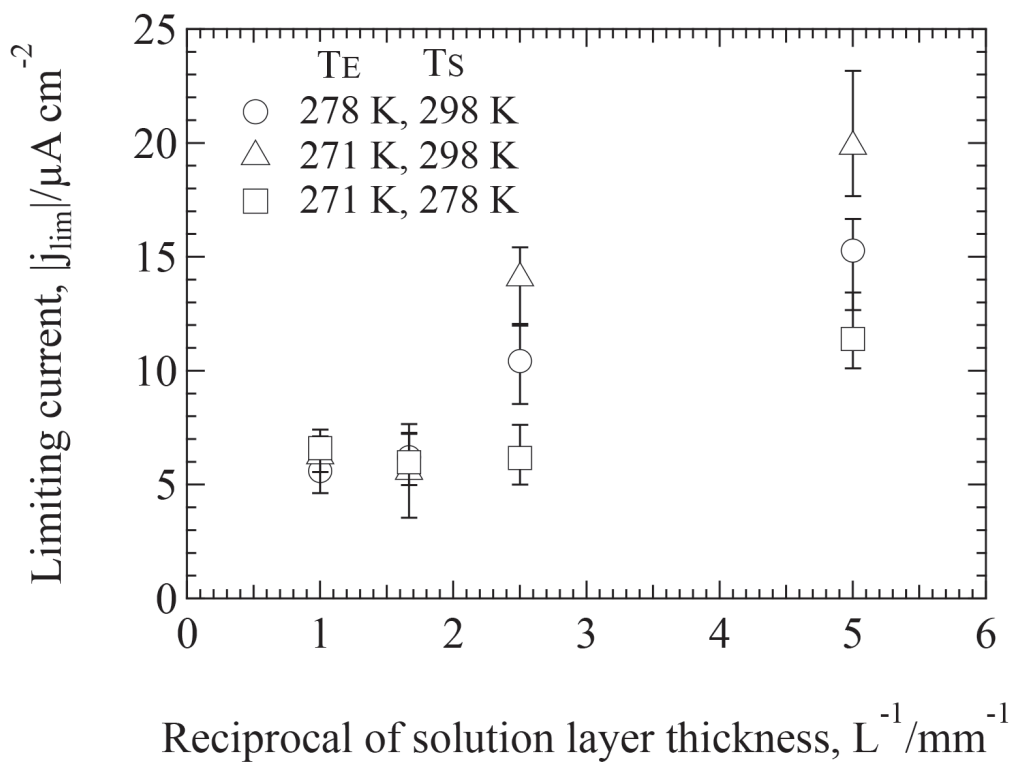




\title{
金属上に形成した水膜中の酸素拡散挙動に及ぼす 水膜厚さと温度差の影響
}

\author{
坂入 正敏 ${ }^{1) *}$ ・谷口 雅也 ${ }^{2)}$ \\ in Thin Solution Layer Formed on Metal \\ Masatoshi SAKAIRI and Masaya TANIGUCHI
}

Effect of Layer Thickness and Temperature Difference on Oxygen Diffusion Behavior

\section{1. 緒言}

構造用鋼の多くは大気環境で使用される。日本の大気 環境は沖縄のような亜熱帯気候から北海道のような亜寒 帯湿潤気候まで幅広く，温度や湿度などの環境条件が大き く異なる。そのため，大気腐食に着目した多くの研究があ る ${ }^{1-12)}$ 。一方，北海道は冬期に低温になり積雪がある積雪 寒冷地である。日本の積雪寒冷地は国土面積の約 $60 \%$ ほど であり，これらは日本海側に広く分布している ${ }^{13)}$

金属材料の大気腐食は電気化学反応であるため, 北海道 のような低温地域において融雪塩の影響がなければ金属材 料の腐食速度は遅いと考えられてきた。しかし，JST東ア ジア共同研究事業 (e-Asia プロジェクト)「環境因子の影響 理解に基づいたアジア地区における構造材料の腐食マッピ ング」(2012 年度〜 2015 年度) の報告から，気温が $10^{\circ} \mathrm{C}$ 以下 において温度が低下すると腐食が進行しやすくなることが 報告された ${ }^{14,15)}$ 。Omoda らは，電気抵抗式腐食センサを用 いて炭素鋼の腐食量の継時変化を 1 年間測定することによ り，高塩害環境においては低温でも 100～200 $\mu \mathrm{m} / \mathrm{y}$ と非常 に速い腐食速度であることを報告した ${ }^{16)}$ 。Esmaily らは，相 対湿度を $95 \%, \mathrm{CO}_{2}$ 濃度を $400 \mathrm{ppm}$ ，温度をー4〜22 ${ }^{\circ} \mathrm{C}$ に制 御した範囲で亜鉛の曝露試験を行った結果，一0.5〜 $22^{\circ} \mathrm{C}$ の温度範囲においては，亜鉛の腐食速度は温度に依存せず ほとんど同じであることを報告した ${ }^{17)}$ 。以上のことは，積 雪寒冷地が温度から予想されるより厳しい腐食環境であ ることを示している。その理由として，Fig.1に示すように （a）降雪により材料表面に積もった雪が，(b) 太陽光によっ て温められた金属板上で水膜を形成し，(c) その水膜を通 じて酸素の供給が加速されるためと考えられる。一方，積 (a)

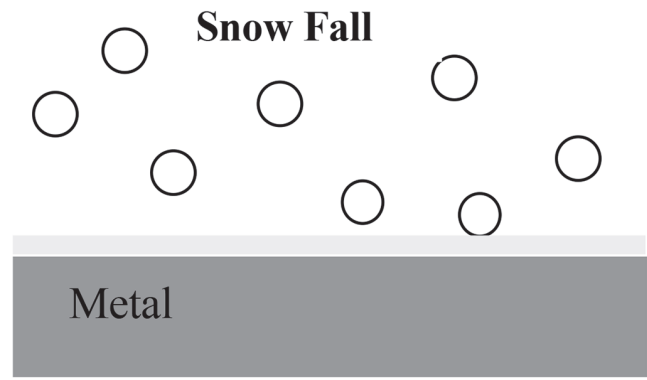

Formation of snow layer Sunlight

(b)

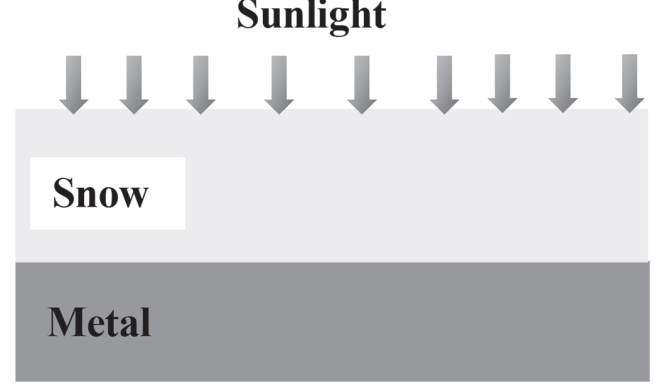

Formation of thin water layer

(c)

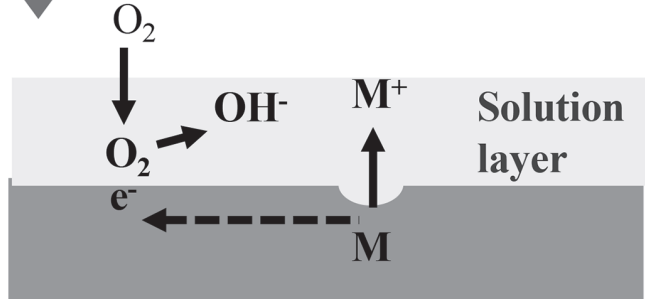

Fig. 1. Schematic representation of (a), (b) formation of solution layer on metals by snow fall and sunlight, and (c) corrosion under formed solution layer.

2）北海道大学大学院工学院 (現 : 日立建機 (株)) (Graduate School of Engineering, Hokkaido University, now Hitachi Construction Machinery Co., Ltd.)

* Corresponding author. E-mail : msakairi@eng.hokudai.ac.jp, Address: Hokkaido University, Kita 13 Nishi 8 Kita-ku Sapporo Hokkaido 060-8628 
雪に含まれるイオンは場所により異なる。Yamaguchiらは, 北海道に打ける酸性雨の観点から積雪の成分を長期にわた り測定し，日本海側沿岸の雪には硫酸イオンや硝酸イオン などが太平洋側沿岸地域より多く含まれていることを報告 している ${ }^{18)}$ 。ののことは, 雪が溶けることにより形成する 水膜中の組成も場所により大きく異なり，水膜下で起こる 腐食も地域依存性が高いことを示唆している。

Fig.2に中性溶液を用いた場合の典型的な $\mathrm{Fe}$ の分極曲線 を模式的に示す。金属材料の腐食は, 電気化学反応であり アノード反応とカソード反応が釣り合った状態で進行す る。Fig.2においてアノード部分分極曲線とカソード部分 分極曲線を外装した交点となる。 $\mathrm{H}^{+}$イオン濃度が低い中 性の溶液において，カソード反応は酸素還元反応が主体と なる。Fig.2に示すように，カソード方向に分極すること電 流が電位により変化しない領域が測定される。この時，カ ソード電流 (カソード反応速度) は, 溶液/金属界面への酸 素の拡散速度により支配される。この状況に打けるカソー ド電流を酸素の拡散限界電流と呼び，カソード反応速度は 酸素の拡散速度に依存することになる。酸素の拡散速度が 変わることは, Fig.2の平坦部の電流值が増減することに対 応する。腐食している金属に打いて，アノード反応 (金属 の溶解反応）が充分に速い場合，カソード反応速度が腐食 速度を支配することになる。つまり，腐食電流(腐食速度) は酸素の拡散限界電流と等しくなる。一方, 大気腐食環境 では，降雨や積雪，温湿度の変化により金属表面は濡れと 乾きを繰り返しているため, 金属材料表面に形成される水 膜の厚さは常に変化する。この厚さ変化により酸素の拡散 速度が変わることで, 拡散限界電流は増減を繰り返す。こ のことは, 酸素の拡散限界電流を調査することが大気腐食 挙動の解明に繋がることを意味し，大気腐食に影響を及ほ す因子を特定する上で, 水膜厚さと酸素の拡散限界電流の

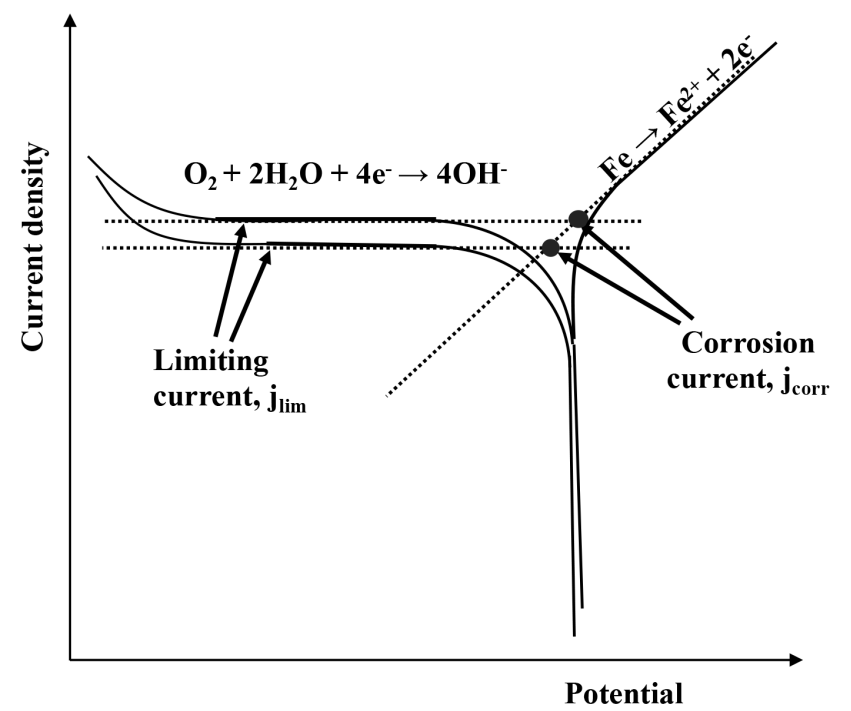

Fig. 2. Schematic representation of effect of oxygen diffusion limiting current on corrosion current.
関係が重要であると言える。この視点から，厚さを制御し た水膜でカソード分極測定を行うことにより，水膜が薄く なるにつれて拡散限界電流が増大することが報告されてい る $^{19-22)}$ 。

e-Asia プロジェクトの報告から, 気温が $10^{\circ} \mathrm{C}$ 以下になる と腐食速度が高くなることが分かってきたので温度も重要 であると言えるが, 酸素の拡散挙動に及ぼす水膜厚さと温 度の影響に関する研究例 ${ }^{23-27)}$ は少ない。本研究においては, 積雪寒冷地に打ける金属の大気腐食挙動を解明するため, 金属上に形成した水膜中に打ける酸素拡散挙動に及ぼす水 膜の厚さや温度勾配の影響を調査することを目的とする。

\section{2. 実験方法}

\section{$2 \cdot 1$ 試料と溶液}

予備実験から炭素鋼を用いて安定に測定できなかった ため, 大気環境で耐食性の高い Zn板 ${ }^{28)}$ を $20 \times 50 \mathrm{~mm}$ に 切り出して試料に用いた。前処理として $\mathrm{SiC}$ 耐水研磨紙で \#2400 まで流水中で研磨後, 高純度水中打よびエタノール 中でそれぞれ300 s 超音波洗浄を行なった。前処理した試 料は直径 $6 \mathrm{~mm}$ の開口を有する樹脂テープを用い, 1 〜 0.2 $\mathrm{mm}$ の範囲で厚さを変えて表面を被覆した。な打, 水膜の 厚さを目視により制御していること, 使用したテープの厚 さの精度などを考慮すると制御精度は $0.05 \mathrm{~mm}$ 程度であ る。溶液には $10 \mathrm{mM} \mathrm{NaCl}$ を用い, 開口部にのみ溶液を満た すことで厚さを変えた水膜を試料上に形成した。

\section{$2 \cdot 2$ 電気化学測定}

電気化学測定として動電位分極測定を行った。測定装 置の模式図を Fig.3に示す。対極にはPt線, 参照電極には $\mathrm{AgCl}$ を電解により $\mathrm{Ag}$ 線に形成した $\mathrm{Ag} / \mathrm{AgCl}$ 電極を用い た。論文中の電位は飽和 $\mathrm{KCl}$ の $\mathrm{Ag} / \mathrm{AgCl}$ 電極基準に変換し て示した。なお，再現性を確認するため同一条件で数回の 測定を実施した。浸漬電位を $600 \mathrm{~s}$ 測定した後, 浸漬電位か らカソード方向へ $20 \mathrm{mV} / \mathrm{min}$ の電位走査速度で動電位分極 を行った。測定時の環境温度, $\mathrm{T}_{\mathrm{E}}$, は断熱容器内で, ウォー ターバスを用いて不凍液を循環することにより制御した。 試料温度， $\mathrm{T}_{\mathrm{S}}$ はペルチェ素子を用いて制御した。寒冷地に おいては，太陽光で熱せられた金属板は環境より温度が高 くなる。このような寒冷地の温度条件を考慮した環境温度 $\mathrm{T}_{\mathrm{E}}$ と試料温度 $\mathrm{T}_{\mathrm{S}}$ の組み合わせを Table 1 に示す。

\section{3. 結果}

\section{$3 \cdot 1$ 温度と水膜厚さの影響}

溶液として $10 \mathrm{mM} \mathrm{NaCl}$ 用い, $\mathrm{T}_{\mathrm{E}}=\mathrm{T}_{\mathrm{S}}$ として温度を 変えて電気化学測定を行った。Fig.4に水膜厚さを $1 \mathrm{~mm}$ に 制御して得られたカソード分極曲線を示す。分極開始電 位 (浸漬電位) は, 温度が低下するに従って貴側に変化し 
ている。温度に関係なく分極を開始すると急激に電流が大 きくなり，その後ほぼ一定の值を示すようになる。Zn電極 に打ける酸素の還元は2段階で起こることが報告されてい

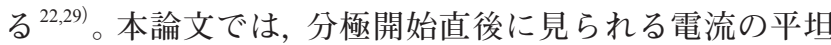
部分である Fig.4のー $1.08 \mathrm{~V}$ から-1.12 Vの平均的な電流 值を酸素の拡散が律速になっている電流 (拡散限界電流) とする。

Fig.5 に拡散限界電流の平均值と水膜厚さの逆数との関 係を示す。いずれの温度においても, 水膜厚さに関わらず 拡散限界電流はほほ変化しない。298 K と $278 \mathrm{~K}$ を比較す ると, 水膜厚さに関係なく, $278 \mathrm{~K}$ の拡散電流值は $298 \mathrm{~K}$ よ

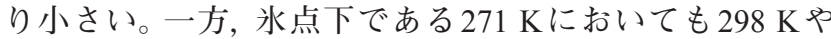
$278 \mathrm{~K}$ の拡散限界電流と同様の傾向を示している。271 K程 度の温度であれば, 酸素の拡散速度は常温とほぼ同じであ ることを示唆している。

\section{$3 \cdot 2$ 温度差と水膜厚さの影響}

寒冷地で使用される鋼構造物や金属材料は, 太陽光によ り暖められるため, $\mathrm{T}_{\mathrm{E}}$ と $\mathrm{T}_{\mathrm{S}}$ は異なる。そこで, $\mathrm{T}_{\mathrm{E}}$ と $\mathrm{T}_{\mathrm{S}}$ の組

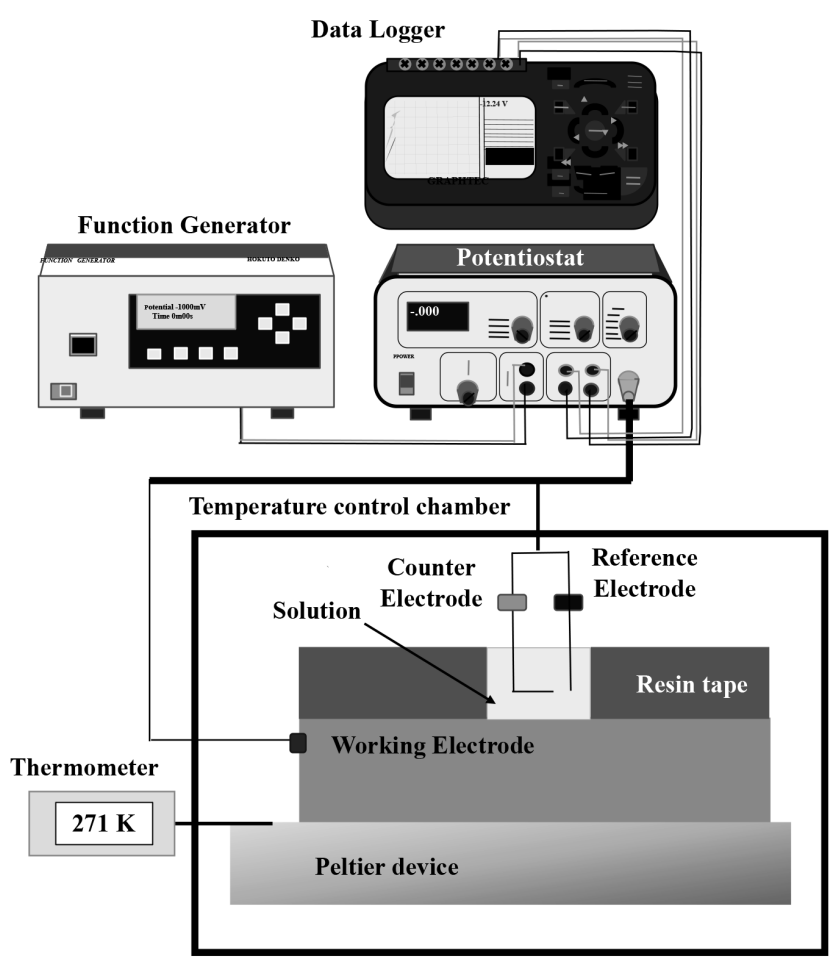

Fig. 3. Schematic representation of electrochemical test setup.

Table 1. Combinations of environmental temperature and sample temperature.

\begin{tabular}{cc}
\hline Environmental temperature, $\mathrm{T}_{\mathrm{E}}(\mathrm{K})$ & Sample temperature, $\mathrm{T}_{\mathrm{S}}(\mathrm{K})$ \\
\hline 298 & 298 \\
\hline 278 & 278 \\
\hline 271 & 271 \\
\hline 278 & 298 \\
\hline 271 & 298 \\
\hline 271 & 278 \\
\hline
\end{tabular}

み合わせを種々変えて電気化学測定を行った。Fig.6に膜厚 さを $1 \mathrm{~mm}$ に制御して得られた，カソード分極曲線を示す。 $\mathrm{T}_{\mathrm{E}}=\mathrm{T}_{\mathrm{S}}$ と同様に, 電位を変化しても電流の変化しない領域 (酸素の拡散限界電流) が得られている。 $\mathrm{T}_{\mathrm{E}}=\mathrm{T}_{\mathrm{S}}$ と同様に $-1.08 \mathrm{~V}$ から $-1.12 \mathrm{~V}$ の電流值を酸素の拡散が律速になっ ている電流 (拡散限界電流) として求めた。Fig.7に拡散限 界電流の平均值と水膜厚さの逆数との関係を示す。水膜が $0.6 \mathrm{~mm}$ より厚い場合, 温度の組み合わせにかかわらずほぼ 同じ値を示している。一方，いずれの温度の組み合わせに 打いても, 水膜厚さが $0.6 \mathrm{~mm}$ より薄くなると水膜厚さの

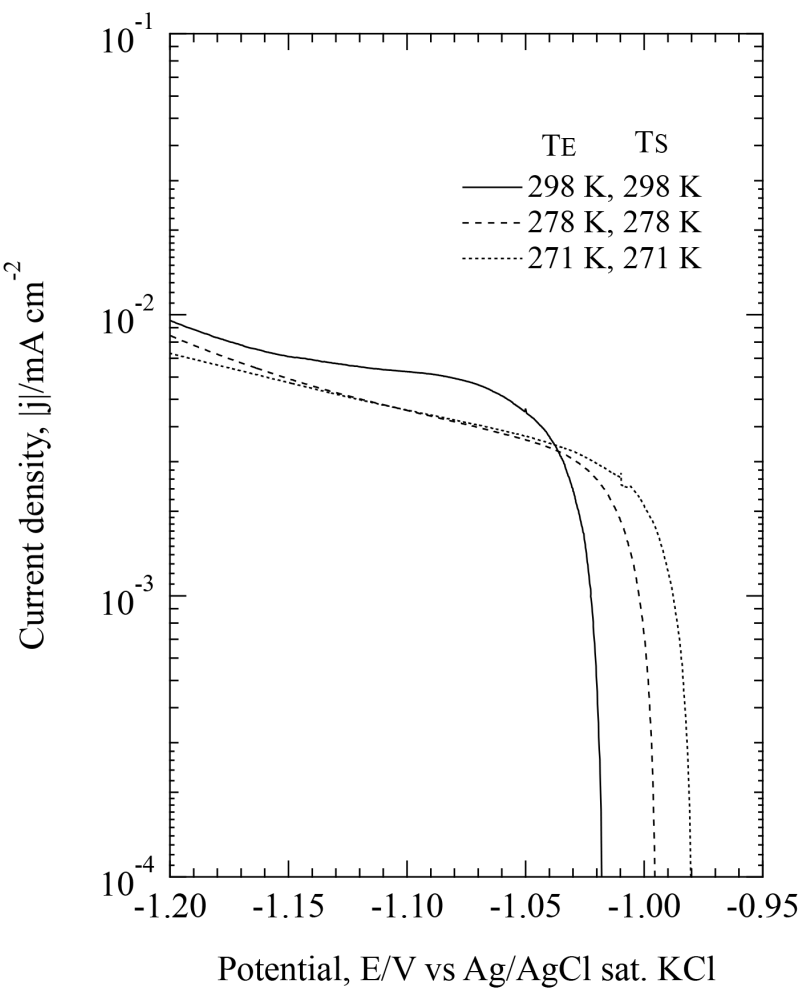

Fig. 4. Cathodic polarization curves under $1 \mathrm{~mm}$ thickness 10 $\mathrm{mM} \mathrm{NaCl}$ solution at $\mathrm{T}_{\mathrm{E}}=\mathrm{T}_{\mathrm{S}}$.

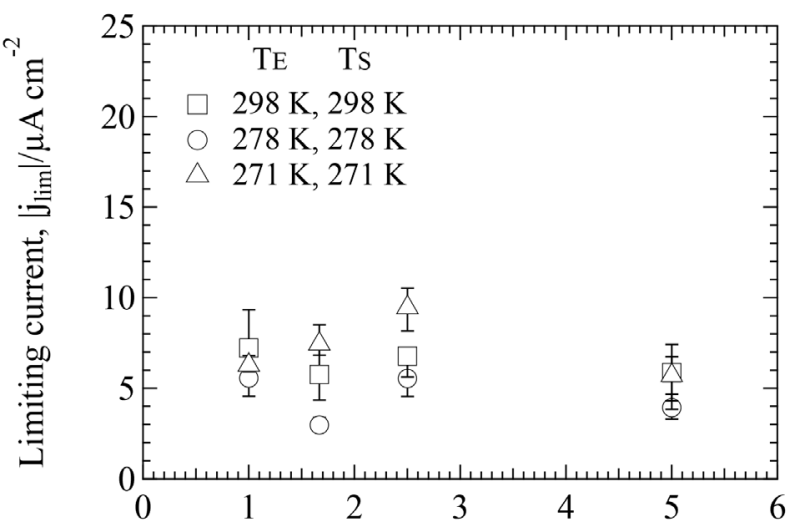

Reciprocal of solution layer thickness, $\mathrm{L}^{-1} / \mathrm{mm}^{-1}$

Fig. 5. Changes in limiting current with reciprocal of solution layer thickness at $\mathrm{T}_{\mathrm{E}}=\mathrm{T}_{\mathrm{S}}$. 
逆数に従って拡散限界電流は大きくなっている。さらに, 水膜が $0.6 \mathrm{~mm}$ より薄い領域において, 拡散限界電流は温 度の組み合わせの影響を受けている。具体的には, 同じ水 膜厚さに拈いて, $\mathrm{T}_{\mathrm{S}}=298 \mathrm{~K}$ と $\mathrm{T}_{\mathrm{E}}=271 \mathrm{~K}$ の拡散限界電流 が最も大きく, $\mathrm{T}_{\mathrm{E}}=271 \mathrm{~K}$ と $\mathrm{T}_{\mathrm{S}}=278 \mathrm{~K}$ の拡散限界電流が 最も小さい。これらの結果は, 水膜が薄くなると水膜の両 界面 (大気/水膜と水膜/金属) に打ける温度の差が水膜中 における酸素の拡散速度に影響を与えることを示唆する。

Fig.6と Fig.7の結果は, 腐食が水膜中の酸素の拡散によ り支配されている大気腐食環境の場合, 環境温度と材料温

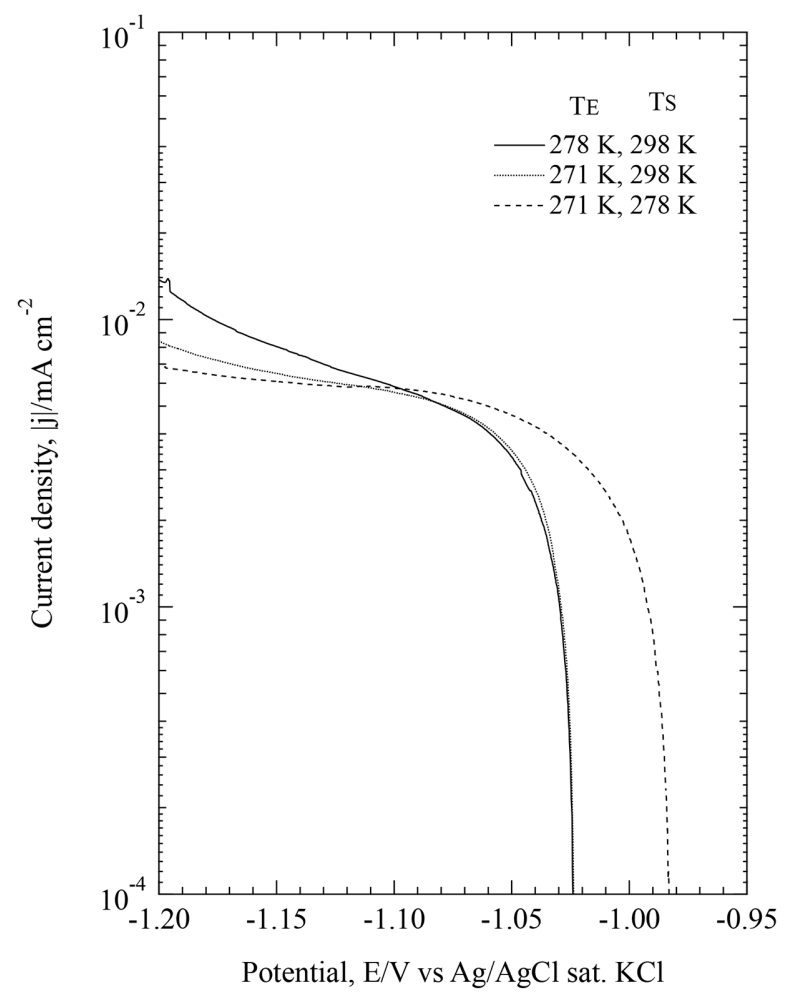

Fig. 6. Cathodic polarization curves under $1 \mathrm{~mm}$ thickness 10 $\mathrm{mM} \mathrm{NaCl}$ solution at different $\mathrm{T}_{\mathrm{E}}$ and $\mathrm{T}_{\mathrm{S}}$.

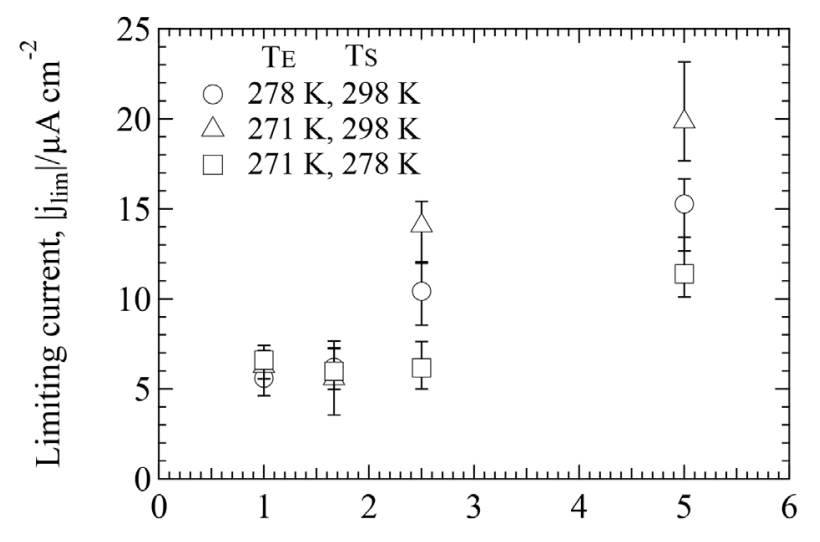

Reciprocal of solution layer thickness, $\mathrm{L}^{-1} / \mathrm{mm}^{-1}$

Fig. 7. Changes in limiting current with reciprocal of solution layer thickness at $\mathrm{T}_{\mathrm{E}}<\mathrm{T}_{\mathrm{S}}$.
度に差があると低温地域の腐食速度が, 高温地域の腐食速 度より大きくなる可能性を示唆している。

\section{4. 考察}

\section{$4 \cdot 1$ 温度差のない水膜中の酸素拡散挙動}

水溶液中の酸素の溶解度はそれほど高くないため, 酸素 還元によるカソード電流は容易に酸素の拡散限界電流に 達する。酸素はカソード反応により消費されるため, 亜鉛 板表面における酸素濃度は $0 \mathrm{mgL}^{-1}$ と仮定し, Nernstの拡 散モデルが成立するとき, 拡散層内の濃度勾配は直線的で ある。Fig.8 に水膜の断面と水膜中の酸素濃度を模式的に示 す。酸素の拡散が律速となっており水膜が拡散層より厚い 場合, 金属側からの距離に従って酸素濃度に勾配が生じて いる拡散層, 一定の酸素濃度である中間層, 環境の影響を 受ける表面層が存在すると予想される。電極 (単位面積) に到達する酸素の流束 $\mathrm{j}_{\mathrm{o}}$ は拡散係数 $\mathrm{D}$ と溶存酸素濃度 $\mathrm{C}_{\mathrm{S}}$ との積に比例し, 拡散距離 $\delta$ に反比例するため, 拡散限界 電流 $\mathrm{j}_{\mathrm{lim}}$ は, $\mathrm{j}_{\mathrm{o}}$ に比例することから次式により表される。

$$
\mathrm{j}_{\lim } \propto \mathrm{j}_{\mathrm{O}}=-\mathrm{D} \frac{\mathrm{Cs}}{\delta}
$$

ここで $D$ は水膜の温度に依存するため, 水膜厚さによら ず同じであると仮定できる。 $\mathrm{T}_{\mathrm{E}}=\mathrm{T}_{\mathrm{S}}$ より, 水膜内部に温度 勾配は存在しないと考えられる。拡散係数と溶存酸素濃度 の温度依存性を Table 2 に示す。温度が低下すると溶存酸素 濃度は上昇する一方で, 酸素の拡散係数は低下する。Fig.5

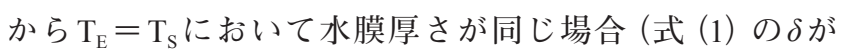
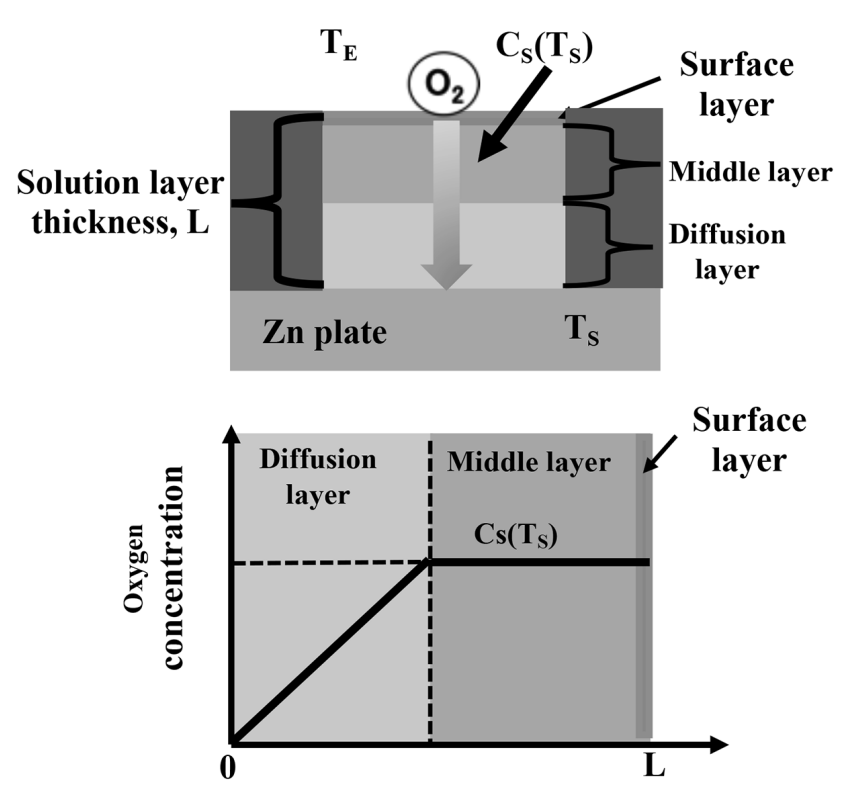

Distance from Zn plate

Fig. 8. Schematic representation of oxygen diffusion at same $\mathrm{T}_{\mathrm{E}}$ and $\mathrm{T}_{\mathrm{S}}$. 
同じ条件)，温度によらず酸素の拡散限界電流は変化して いない。このことから，いずれの温度に打いても式 (1) の $\mathrm{D} \times \mathrm{C}_{\mathrm{S}}$ が一定となったため, 拡散限界電流が変化しなかっ たことが示唆される。一方, Fig. 5 から, $\mathrm{T}_{\mathrm{E}}=\mathrm{T}_{\mathrm{S}}$ において酸 素の拡散限界電流が水膜厚さに依存していない。この理由 については，さらなる実験と検討が必要である。

\section{$4 \cdot 2$ 温度差を有する水膜中の酸素拡散挙動}

拡散限界電流が測定されている際の $\mathrm{T}_{\mathrm{E}}<\mathrm{T}_{\mathrm{S}}$ の例として, $\mathrm{T}_{\mathrm{E}}=271 \mathrm{~K}, \mathrm{~T}_{\mathrm{S}}=298 \mathrm{~K}$ に制御した際の水膜が厚い場合 (左 四）と薄い場合 (右図) の水膜の状況と水膜中の溶存酸素 濃度分布を Fig.9 に模式的に示す。 $\mathrm{T}_{\mathrm{E}}=\mathrm{T}_{\mathrm{S}}$ の場合と同様に, 酸素の拡散限界電流が測定される条件において, 酸素はカ ソード反応により消費されるため亜鉛板表面における酸 素濃度は $0 \mathrm{mgL}^{-1}$ と仮定する。4・1で述べたように酸素 の拡散が律速となっており水膜が拡散層より厚い場合，酸 素濃度に勾配が生じている拡散層，一定の酸素濃度である 中間層，大気の影響を受ける表面層が存在すると予想され る。水膜が薄くなると，中間層がなくなり表面層と拡散層 の2層構造になると予想される。表面層は環境と接してい るため環境温度の影響を受ける。一方，測定環境に一定時

Table 2. Oxygen diffusion coefficient and oxygen content in aqueous solution at different temperatures.

\begin{tabular}{cccccc}
\hline $\mathrm{T}$ & $271 \mathrm{~K}$ & & $278 \mathrm{~K}$ & & $298 \mathrm{~K}$ \\
\hline $\mathrm{D}(\mathrm{T})$ & $\mathrm{D}(271 \mathrm{~K})$ & $<$ & $\mathrm{D}(278 \mathrm{~K})$ & $<$ & $\mathrm{D}(298 \mathrm{~K})$ \\
\hline $\mathrm{C}_{\mathrm{S}}(\mathrm{T})$ & $\mathrm{C}_{\mathrm{S}}(271 \mathrm{~K})$ & $>$ & $\mathrm{C}_{\mathrm{S}}(278 \mathrm{~K})$ & $>$ & $\mathrm{C}_{\mathrm{S}}(298 \mathrm{~K})$ \\
\hline
\end{tabular}

\section{Thick solution layer}
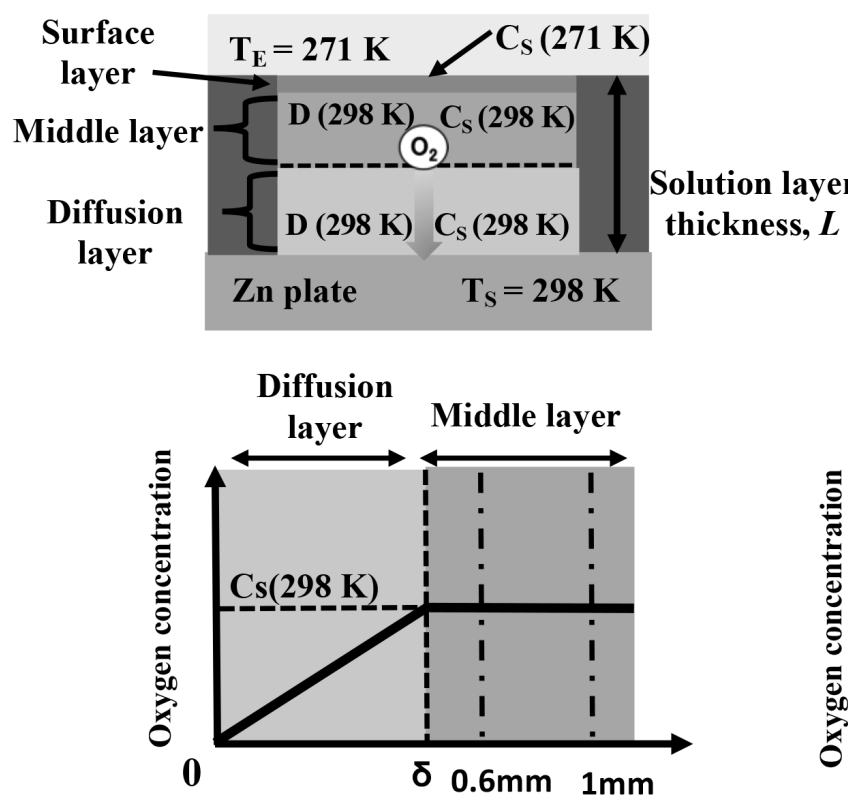

Distance from $\mathrm{Zn}$ plate
間保持後に測定してから測定を開始したこと，拡散層と中 間層内に温度勾配があると対流が生じて温度の均一化が発 生すると考えられることから, 拡散層と中間層の温度は試 料温度の影響を受けて $\mathrm{T}_{\mathrm{S}}$ と同じ $298 \mathrm{~K}$ であると言える。そ のため, 表面層の酸素濃度は水膜厚さに関わらず環境温度 $\left(\mathrm{T}_{\mathrm{E}}=271 \mathrm{~K}\right)$ に打ける濃度, $\mathrm{C}_{\mathrm{S}}(271 \mathrm{~K})$ に, 中間層の溶存 酸素濃度は $\mathrm{T}_{\mathrm{S}}=298 \mathrm{~K}$ に打ける濃度, $\mathrm{C}_{\mathrm{S}}(298 \mathrm{~K})$ になる。 拡散層の酸素濃度は, Fig.9の水膜中の溶存酸素濃度分布図 に示すようにZn電極からの距離に従って直線的に変化す る。各層の Dについても, $\mathrm{C}_{\mathrm{s}}$ と同様に温度の影響を受ける と考えられる。

水膜が厚い場合, Fig.9に示すように酸素の拡散速度に影 響する $\mathrm{C}_{\mathrm{S}}$ と D は， $\mathrm{T}_{\mathrm{S}}$ の影響を受ける。それぞれの温度依存 性はTable 2 に示したようになる。しかし, Fig.7に打いて水 膜が厚い場合, 酸素の拡散限界電流は $\mathrm{T}_{\mathrm{E}}$ と $\mathrm{T}_{\mathrm{S}}$ の影響を受 けなかった。このことから $\mathrm{D} \times \mathrm{C}_{\mathrm{s}}$ は, 温度が変化しても一 定だったことが示唆される。

水膜が薄い場合, Fig.9 水膜中の溶存酸素濃度分布図にお いて水膜内の酸素濃度に傾きが生じる位置における $\mathrm{C}_{\mathrm{s}}$ は, 表面層のそれであるため $\mathrm{T}_{\mathrm{E}}$ の影響を受ける。Table 2 に示 した様に $\mathrm{C}_{\mathrm{S}}$ は温度が低下すると増加するため, Fig.9 水膜 中の溶存酸素濃度分布図で傾きが大きくなる。酸素の拡散 速度に寄与する Dは前述したように $\mathrm{T}_{\mathrm{S}}$ の影響を受ける。 $\mathrm{T}_{\mathrm{S}}$ と水膜厚さが同じ場合, 式 (1) から $\mathrm{T}_{\mathrm{E}}$ が $298 \mathrm{~K}$ から $271 \mathrm{~K}$ に低下すると酸素の拡散限界電流が大きくなることを意味 する。一方, $\mathrm{T}_{\mathrm{E}}$ と水膜厚さが同じ場合, $\mathrm{T}_{\mathrm{S}}$ が $298 \mathrm{~K}$ から 278

\section{Thin solution layer}
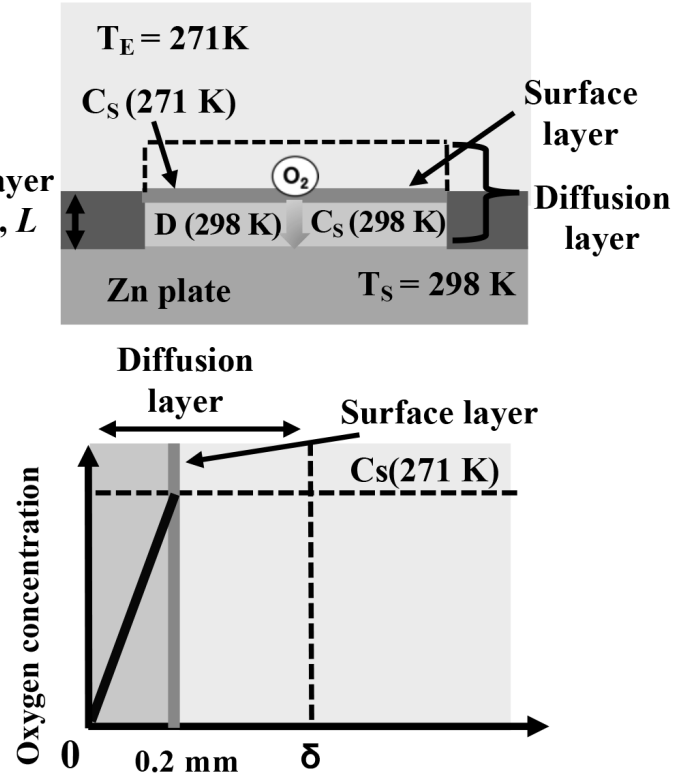

\section{Distance from $\mathrm{Zn}$ plate}

Fig. 9. Schematic representation of oxygen diffusion in different thickness solution layer at combination of $T_{E}$ and $T_{S}$. 
K に低下寸ると，拡散層の Dも小さくなる。そのため，式 (1) から Fig.7に示されたように酸素の拡散限界電流は小 さくなったと考えられる。

水膜が薄くなるに従って酸素の拡散距離は短くなるが, $\mathrm{T}_{\mathrm{E}}, \mathrm{T}_{\mathrm{S}}$ が同じ組み合わせにおいては酸素の拡散速度に影響 する $\mathrm{C}_{\mathrm{s}}$ と Dは変化しない。式 (1) の右辺は水膜厚さに依存 して変化することになり, 酸素の拡散限界電流は水膜厚さ が薄くなるに従って大きくなる。このことが, Fig.7で0.6 $\mathrm{mm}$ より薄い領域において $\mathrm{T}_{\mathrm{E}}, \mathrm{T}_{\mathrm{S}}$ が同じ組み合わせの場合 に水膜が薄くなるに従って電流が大きくなった理由と考え られる。

本論文の結果は, 金属表面に降り積もった雪が太陽光に より温められることで水膜が形成した場合, 水点より低い 温度でも金属の腐食は進行すること, 形成する水膜の厚さ によっては寒冷地に打ける腐食速度が温暖な地域より速い ことを示唆している。

\section{5. 結言}

環境温度と試料温度を種々組み合わせ, 厚さを変えた水 膜下でカソード分極測定から酸素の拡散限界電流を求め た。その結果，以下の結論を得た。

(1) 環境温度と試料温度が等しい場合, 酸素の拡散限界電 流は温度の影響を受けない。

(2) 環境温度が $271 \mathrm{~K} て ゙$ 試料温度が $278 \mathrm{~K}$ と $298 \mathrm{~K}$ の場合, 水膜が $0.6 \mathrm{~mm}$ より薄くなると酸素の拡散限界電流は 大きくなる。環境温度が同じで水膜が $0.6 \mathrm{~mm}$ より薄い 場合, 試料温度が高くなると酸素の拡散限界電流は大 きくなる。

（3）試料温度が $298 \mathrm{~K}$ で環境温度が $298 \mathrm{~K} よ り$ 低い場合, 水膜が $0.6 \mathrm{~mm}$ より薄くなると水膜厚さが薄くなるに 従って酸素の拡散限界電流は大きくなる。水膜が 0.6 $\mathrm{mm}$ より薄い場合, 環境温度が低くなるに従って酸素 の拡散限界電流は大きくなる。

\section{謝辞}

本研究は, 2017 年度と 2020 年度北海道ガス大学研究支 援制度の援助により実施された。

\section{文献}

1) A.Niahikata, S.Kumagai and T.Tsuru: Zairyo-to-Kankyo, 43(1994), 82 (in Japanese).

2 ) T.Yamazaki, A.Nishikata and T.Tsuru: Zairyo-to-Kankyo, 50(2001), 30 (in Japanese).

3 ) M.Yamanoto, H.Katayama and T.Kodama: J. Jpn. Inst. Met., 65(2001), 465 (in Japanese).
4 ) E.Shafiei, M.Zeinali and A.R.Nasre Esfahani: ISIJ Int., 51(2011), 1878.

5 ) D.Mizuno, S.Suzuki, S.Fujita and N.Hara: Corros. Sci., 82(2014), 217.

6 ) Z.Zhang, S.Yang, H.Guo and X.He: ISIJ Int., 54(2014), 909.

7 ) M.Omoda, H.Harada, H.Kajiyama and M.Kimura: Zairyo-toKankyo, 65(2016), 274 (in Japanese).

8 ) M.Nagasawa, N.Okada, N.Otsuka and T.Ohtsuka: ISIJ Int., 58(2018), 316

9 ) M.Morcillo, I.Díaz, H.Cano, B.Chico and D.de la Fuente: Constr. Build. Mater., 213(2019), 723.

10) H.S.Palsson, K.Wongpinkaew, P.Khamsuk and W.Pongsaksawad: Mater. Corros., 71(2020), 1019.

11) H.Sato, M.Nagasawa, M.Kaneko and H.Iki: Zairyo-to-Kankyo, 69(2020), 69 (in Japanese).

12) R.Onishi, K.Matsuda, H.Suto, Y.Hattori, H.Hiraguchi, S.Matsunami, S.Yagyu, T.Shinohara and H.Katayama: Zairyo-toKankyo, 69(2020), 169 (in Japanese).

13) H.Yamada, S.Kawasaki, K.Kiyasu, Y.Fukuda, H.Makino, T.Toba, H.Ouchi, S.Mizuguchi, M.Yoasa, Y.Kaziya, M.Matsuzaki and T.Suzuki: The Results Report of Joint Research about Cruise-Assist Technology in a Winter Road, Technical Note of National Institute for Land and Infrastructure Management No.178, National Institute for Land and Infrastructure Management, Tsukuba, (2004), 2 (in Japanese).

14) T.Shinohara, A.Tahara and T.Dara: Proc. JSCE Materials and Environments 2016, Japan Society of Corrosion Engineering, Tokyo (2016), C-111 (in Japanese).

15) T.Shinohara, A.Tahara and T.Dara: Proc. 5th Asian Materials Data Symposium, Publication House for Science and Technology, Hanoi, (2016), 85 .

16) M.Omoda, D.Mizuno, N.Ishikawa and S.Fujita: Proc. 65th Japan Conference on Materials and Environments, Japan Society of Corrosion Engineering, Tokyo, (2018), A307 (in Japanese).

17) M.Esmaily, N.Mortazavi, J.E.Svensson and L.G.Johansson: $J$. Electrochem. Soc., 163(2016), C864.

18) T.Yamaguchi, I.Noguchi, H.Aga, R.Iwata, Y.Ueno, M.Akiyama, H.Otsuka, S.Sakai, S.Nagohra, K.Yamaguchi, S.Niwa, H.Ohara, T.Tanaka, K.Anezuki and K.Hamahara: Report of Hokkaido Institute of Environmental Sciences, Hokkaido Institute of Environmental Sciences, Sapporo, 35(2009), 61 (in Japanese).

19) A.Nishikata, Y.Ichihara, Y.Hayashi and T.Tsutu: J. Electrochem. Soc., 144(1997), 1244.

20) M.Stratmann, H.Streckel, K.T.Kim and S.Crockett: Corros. Sci., 30(1990), 715 .

21) A.Nishikata and T.Ohtsuka: Electrochemistry, 83(2015), 483.

22) A.Nishikata: Zairyo-to-Kankyo, 65(2016), 120 (in Japanese).

23) M.Sakairi and R.Sakaki: Zairyo-to-Kankyo, 66(2017), 401 (in Japanese).

24) M.Sakaki and R.Sakaki: ECS Trans., 75(2017), 61.

25) M.Taniguchi and M.Sakairi: Abstracts of 18th Asian Pacific Corrosion Control Conf., MTEC, Bangkok, (2018), CS-038.

26) M.Taniguchi and M.Sakairi: Proc. NACE East Asia and Pacific Area Conf. 2019, NACE Tokyo, Tokyo, (2019), EAPA19NOV-14075.

27) M.Taniguchi and M.Sakairi: Rust Prev. Control Jpn., 64(2020), 212 (in Japanese).

28) T.Shinohara: J. Surf. Finish. Soc. Jpn., 62(2011), 25 (in Japanese).

29) A.Yadiv, A.Nishikata and T.Tsuru: J. Electroanal. Chem., 585(2005), 142. 